\title{
The Nutrient Management Improvement of Rice Culture in the Freshwater Swampland
}

\author{
Etik Puji Handayani ${ }^{1, *}$, Isak Juarsah ${ }^{1}$, Rakhmiati $^{1}$, Ainin niswati ${ }^{2}$ \\ ${ }^{1}$ Agrotechnology, STIPER Dharma Wacana, Kenanga Street No.3 Mulyojati 16 C Metro, 34125 \\ Lampung, Indonesia. \\ 2 Department of Soil Science, University of Lampung, Sumantri Brojonegoro Street No. 1, Gedong \\ Meneng, Rajabasa, Bandar Lampung, 35145 Lampung, Indonesia
}

\begin{abstract}
The new challenge for Indonesian food security in the future depends on the productivity of rice on the sub-optimal land, including freshwater swampland. It is a specific and unique characteristic of rice culture. This study aims to analyze opportunities for innovating technology applied to improve the availability of nutrients based on the existing nutrient in freshwater swampland. The soil survey method by purposive and random samplings used to the composite soil sampling in the two sub-district in Banyuasin District, South Sumatera Province, then analyzed in the laboratory. Data collected analysis through descriptive statistics. The results showed that Rice cultivation in the freshwater swampland was a profitable venture. Unavailability of $\mathrm{P}$ nutrients for rice plants was the main problem on acidic soil ( $\mathrm{pH} 3.32-4.12)$, caused by increased the solubility of $\mathrm{Fe}$ and Al. Hence the adoption of farmers to various technological innovations such as liming, fertilization, and amelioration to increase soil $\mathrm{pH}$ is the key to success in rice culture in the freshwater swampland besides growing tolerant varieties.
\end{abstract}

\section{INTRODUCTION}

Agricultural development on the freshwater swampland was one strategy to exploit potential natural resources optimally for rice field expansion in Indonesia. The specific and uniqueness of rice culture on freshwater swampland was the planting process starts on the dry season. In this unavailability of water supply, so other regions in Indonesia, nothing plant rice. The water in swampland influenced by a river overflow, rainfall, and inundated during the rainy season and gradually dries in the dry season [1]. The strategies to increasing rice productivity on swampland consisting of yield safety through using rice variety tolerant, water management, fertilization, soil tillage, pest and disease control, and improvement of the social-economic aspect of the farmer [2]. Climate change current, notably on changes in temperature and rainfall, impacts the increasingly complex challenges faced in increasing rice production in the freshwater swampland besides nutrient stress, weeds, pests, and diseases [3].

\footnotetext{
*Corresponding author: etikpuji68@gmail.com
} 
Obtaining genotypes that can efficiently mine nutrient and adaptive could be enhancing and sustaining yields in low input agricultural systems. Before the green revolution, the farmers have been cultivating the type local called pegagan. This rice was tolerant of environmental stresses, pest resistance, and grain rice relatively hard [1]. The agromorphological traits could be used efficiently to characterize the rice cultivars [4]. The study of strain and variety yields on the swampy freshwater land has developed rapidly. B11586F-MR-11-2-2, having iron toxicity tolerance, resistance to rice tungro virus, and high milling recovery. Moreover, these lines have passed the Indonesian national variety release committee targeted for dissemination and adoption in the swampy areas. Various superior varieties such as Inpara 1-5 adaptive in swampland Aceh, have yield potential 5.88 - 6.62 $\mathrm{t} / \mathrm{ha}$ in Merauke Regency [5] and is higher than the Mekongga variety [6]. In contrast to [7] that Inpara Variety 1, 2, 3, 4 are more suitable for acid sulfate soils, and Inpara 5 variety is more suitable for planting in the freshwater swamp land.

Recent improvements in breeding methods have increased rice production, but there is another main problem that caused lower rice production in the freshwater swampland. This research concentrates on nutritional deficiencies $\mathrm{P}$ and toxicity $\mathrm{Al}^{3+}$ and $\mathrm{Fe}^{3+}$ in freshwater swampland as the crucial problems of rice culture.

Soil analysis was an approach that could determine nutrient status on assessing the level of soil fertility, which has the concept that the higher the plant's ability to absorb nutrients, the more top results obtained. Nutrient absorption is the ability of the plant relative to mine nutrients from the soil and turns it into a part of the plant. Therefore, database nutrient status plays a vital role in the maintenance of the availability of macronutrients for rice plants and the adverse effects of toxic compounds that arise due to inundation conditions and drought that cannot yet be predicted, depending on hydro topographic conditions, rainfall and local river water levels on swampland.

Although some research has been carried out to increase rice production, there have been few empirical investigations on improvement management nutrients in freshwater swampland. It is useful to decide the best choices of technological innovation rice cultivation. Managing swampland for rice culture is challenged by the multiple constraints of soil acidity e.g. low $\mathrm{pH}$ and cation exchange capacity, low nutrient concentration and retention (high leaching), small beneficial microbe population, activity and diversity, toxicity of $\mathrm{Al}, \mathrm{Mn}$ or $\mathrm{Fe}$, high $\mathrm{P}$ fixation, and low Mo micronutrients [8, 9]. Furthermore, micronutrient content such as $\mathrm{Al}, \mathrm{Fe}, \mathrm{Mn}, \mathrm{B}$, and $\mathrm{S}$ are in the high category. Aluminum dissolves in the soil solution to yield $\mathrm{Al}^{3+}$. In acidic soil conditions, $\mathrm{Al}$ is highly phytotoxic. It quickly affects root growth, ultimately causing a stunted root system and influencing the capability of a plant to uptake both nutrients and water $[7,10]$. In contrast to the problem of high $\mathrm{Na}^{+}$, which caused damage to plant cells in tidal swamps and the appearance of pyrite in acid sulfate soils [11].

This study was conducted to analyze the opportunities for innovating technology applied to improve the availability of nutrients in rice culture based on the existing nutrient in freshwater swampland.

\section{MATERIALS AND METHODS}

\subsection{The study area}

The study was conducted in the Rambutan and the Banyuasin I sub-districts, the Banyuasin District, South Sumatra Province, which located at 02 $43^{\prime} 48^{\prime \prime}-03^{\circ} 09^{\prime} 00^{\prime \prime}$ South Latitude and $104^{\circ} 10^{\prime} 48^{\prime \prime}$ - 10507'12" East Longitude. 


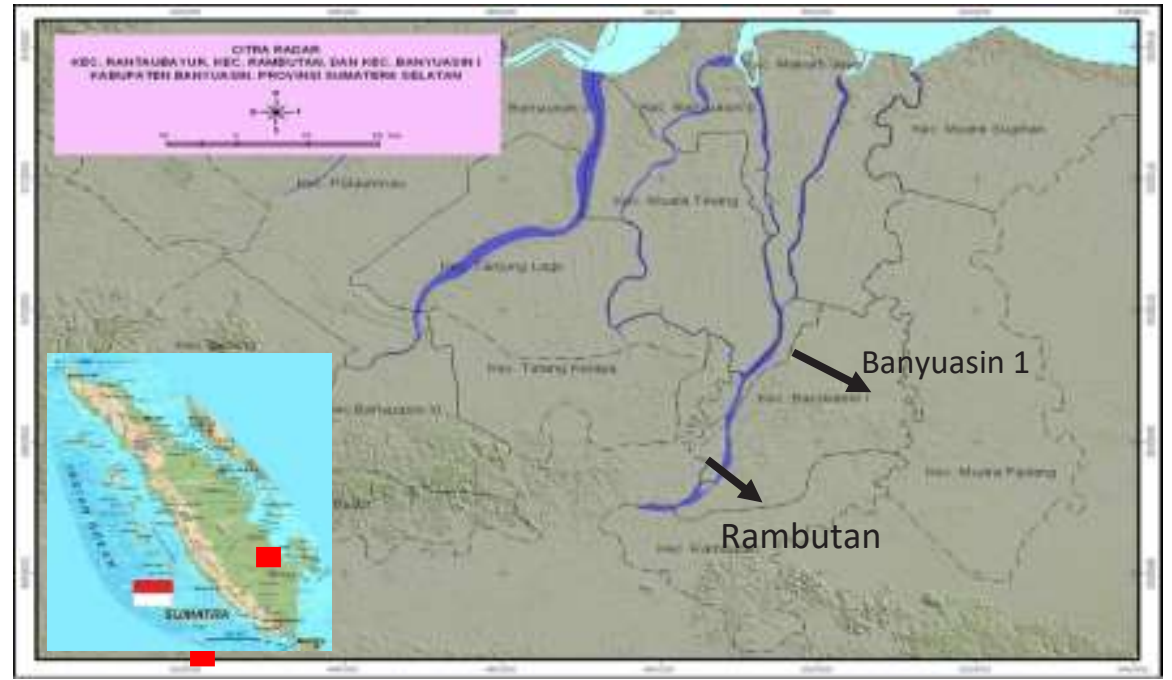

Fig. 1. The research location from Radar Image

\subsection{Field Survey and Data Accumulation}

Purposive and simple random samplings were used in the selection of the field study. Two sub-districts (the Rambutan and the Banyuasin I) that are a rice production freshwater swampland were selected purposively from seventeen sub-districts in Banyuasin District. Each sub-district have six survey locations freshwater swampland.

The composite soil sample is a soil sampling technique at 5 points taken at a depth of 0 $20 \mathrm{~cm}$. The method used is simple random sampling. The soil samples should be taken in moist to wet conditions. The single soil sampling involves drilling the soil at a depth of 0-20 $\mathrm{cm}$, stirred evenly in a plastic bucket, clean soil samples from plants, roots, and animals carried. As for the moist soil, the soil samples that are ready to be analyzed were taken by the syringe. The wet soil surface is pierced with a needle as deep as $5 \mathrm{~cm}$ and removed. Clean and flatten the surface of the syringe, pushed out, and cut into a soil sample of about $0.5 \mathrm{~cm}$ with a stainless spoon, then put in a test tube.

Primary data were collecting by interviews respondents from the Rambutan and the Banyuasin I sub-district which intensive cultivation rice in the freshwater swampland.. Data includes farmer's lifehood and rice cultivation production facilities. Primary data was supported by secondary data obtained from statistical data sources and Village Monographs.

\subsection{Data analysis}

The composite soil sample was carried out at the Soil and Agroclimate Research Center Laboratory, Bogor, Indonesia. Determination of the chemical properties include: (1) $\mathrm{pH}$ extracted by $\mathrm{H}_{2} \mathrm{O}$ and $1 \mathrm{M} \mathrm{KCl}$ measured with the $\mathrm{pH}$ electrode, (2) C-Organic, wet digestion in $\mathrm{K}_{2} \mathrm{Cr}_{2} \mathrm{O}_{7}$ with Walkley and Black method, (3) total-N content with Kjeldahl method. Soil analysis data were described as the current nutrient status of the freshwater swampland in Banyuasin with avarage and standard deviation calculating: 


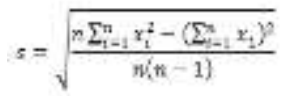

$\left(\mathrm{s}=\right.$ Standar deviation, $\mathrm{xi}=$ value $\mathrm{x}-\mathrm{i}, \mathrm{x}^{-}=$Mean, $\mathrm{n}=$ total sampel $)$

\section{Results and Discussion}

Rice culture in the freshwater swampland supports a sufficient stock of rice for Indonesia, especially in the dry season. The perspective of potential nutrient management will be discussed in this paper, specially content of organic matter and soil acidity which cop to increase rice production.

The results of soil analysis showed that the degree of acidity of the freshwater swampland in the Rambutan and the Banyuasin I sub-district categorized very high, classified as very acid soils. Soil $\mathrm{pH}$ analyzes extracted with $\mathrm{H}_{2} \mathrm{O}$ ranges from 3.42 to 4.12 and $\mathrm{pH}$ extracted by $\mathrm{KCl}$ from 3.28 to 3.75 (Table 1 ).

Table 1. Soil analysis of The content of organic matter and soil acidity status

\begin{tabular}{|c|c|c|c|c|c|}
\hline \multirow[t]{3}{*}{ Location } & \multicolumn{3}{|c|}{ organic matter } & \multicolumn{2}{|c|}{ pH (1:5) } \\
\hline & $\mathrm{C}$ & $\mathbf{N}$ & $\mathrm{C} / \mathrm{N}$ & \multirow[t]{2}{*}{$\mathrm{H}_{2} \mathrm{O}$} & \multirow[t]{2}{*}{$\mathrm{KCl}$} \\
\hline & \multicolumn{3}{|c|}{$\%$} & & \\
\hline Rambutan 1 & 4.58 & 0.24 & 19 & 3.73 & 3.45 \\
\hline Rambutan 2 & 2.52 & 0.09 & 26 & 4.04 & 3.75 \\
\hline Rambutan 3 & 3.80 & 0.23 & 17 & 3.61 & 3.32 \\
\hline Rambutan 4 & 5.62 & 0.08 & 27 & 3.68 & 3.37 \\
\hline Rambutan 5 & 2.21 & 0.41 & 14 & 3.83 & 3.55 \\
\hline Rambutan 6 & 2.76 & 0.12 & 22 & 3.81 & 3.44 \\
\hline STDev & 1.33 & 0.13 & 5.12 & 0.15 & 0.15 \\
\hline Avarage & 3.58 & 0.20 & 20.83 & 3.78 & 3.48 \\
\hline Banyuasin1 & 8.42 & 0.48 & 18 & 3.42 & 3.40 \\
\hline Banyuasin 2 & 5.26 & 0.27 & 19 & 3.51 & 3.28 \\
\hline Banyuasin 3 & 3.20 & 0.36 & 15 & 3.90 & 3.45 \\
\hline Banyuasin 4 & 5.24 & 0.14 & 23 & 4.12 & 3.49 \\
\hline Banyuasin 5 & 2.31 & 0.29 & 18 & 3.94 & 3.59 \\
\hline Banyuasin 6 & 7.94 & 0.31 & 25 & 3.55 & 3.38 \\
\hline STDev & 2.45 & 0.11 & 3.67 & 0.28 & 0.11 \\
\hline Avarage & 5.40 & 0.31 & 19.67 & 3.74 & 3.43 \\
\hline
\end{tabular}

The freshwater swampland as well as swampy tidal, and peatland have high acidity. Because of the freshwater swampland was classified as peatymineral, accordingly it has a higher $\mathrm{pH}$ value (Table 1). The results of the research by [12] showed the chemical characteristic of peatsoil was $\mathrm{pH} \mathrm{H}_{2} \mathrm{O} 2.9$ - 3.9, $\mathrm{pH} \mathrm{KCl} 2.23$ - 3.07. Water content per unit dry weight depends on peatland maturity (fibric: 540 - 1187\%, hemic: 268 - 480\% and sapric: $106-242 \%$ ), ash content per unit dry weight varied from $1.8-5.9 \%$, and C-organic content $53.4-57.6 \%$.

The problem of acidity in these soils was affects the production of rice, but the causes of low crop production in the two soils are different. The main problem in freshwater swampland was deficiency $\mathrm{P}$ and mineral toxicity, whereas in peatland is high organic acids. Therefore, nutrient management in the two soils classified as acid soils must be different.

Previous studies have shown that the soil which strongly acid under the anaerobic condition would increase exchangeable $\mathrm{Al}$ and $\mathrm{Fe}$, futhur reducing $\mathrm{P}$ availability. It can be in the case of rice production in swampland generally low, only 1-2 t.ha ${ }^{-1}[7,10]$. Freshwater swampland in Poso District contains a very high total Fe, i.e., 1.16 - 2.26\% [13]. As a 
consequence of this, it may cause nutrient imbalance through its antagonistic impact on the fixation of nutrients, including $\mathrm{K}, \mathrm{P}, \mathrm{Mn}$, and $\mathrm{Zn}$. While the runoff or the rainfall abundant, occurred reduction conditions. In this condition, $\mathrm{Fe}^{3+}$ was reduced and caused increased $\mathrm{Fe}^{2+}$ solubility, which toxic for the plant [14]. It made a stunted root system and obstruct the capability of absorption nutrients and water [15]. Thus, Fe poisoning is the main problem in increasing rice production in the swampy freshwater land and causing low rice productivity.

The finding of this study has a number of important implications for future fertilizer practice, such as dosage and method application of fertilizer. Low estimates of average availability $\mathrm{P}$ was $11.03 \mathrm{Mg} \cdot \mathrm{kg}^{-1}$ can be caused by the high acidity of the soil, the solubility of $\mathrm{Al}^{3+}$ as being a source of soil acidity beside $\mathrm{H}^{+}, \mathrm{Al}^{3+}$ can also cause $\mathrm{P}$ nutrient unavailability due to the formation of Al-P bonds. The low availability of $\mathrm{P}$ in this the swampland is associated with low soil $\mathrm{pH}$ and high solubility of Fe. [10] explained that the increase in $\mathrm{Fe}$ solubility control in very acid soils needs to overcome the formation of Fe-P or Occlude-P bonds so that the availability of $\mathrm{P}$ for rice plants increases.

Another problem with P-total and P-available was varying considerably standard deviation. The average P-total in the Rambutan sub-district was $23.2 \mathrm{mg} .100 \mathrm{~g}^{-1}$ with standard deviation 21.52, while in Banyuasin I sub-districts was $29.17 \mathrm{mg} .100 \mathrm{~g}^{-1}$ with standard deviation 25.75. Compared with P-available in Rambutan sub-district was 11,03 Mg.kg-1 with standard deviation 9.13, while in Banyuasin I sub-districts was $25.29 \mathrm{Mg} . \mathrm{kg}^{-1}$ with standard deviation 26.9. Although there is an inconsistency with standard deviation value, the information on standard deviation $\mathrm{K}$ and $\mathrm{P}$ in the Banyuasin I sub-district bigger than the Rambutan would help the farmer to establish a higher degree of accuracy of the availability $\mathrm{K}$ and $\mathrm{P}$ depends on the location of the swampland.

The efforts to increase soil $\mathrm{pH}$ in swampland are important because the maximum solubility of phosphate ions from fertilizers or in native soils was at $\mathrm{pH} 5.0$, even $6.0-6.5$ [16]. In general, liming can increase soil $\mathrm{pH}$, reduce soil acidity and $\mathrm{Al}$ toxicity [8], improve soil fertility, soil $\mathrm{pH}$, cation exchange capacity, swapped $\mathrm{Ca}, \mathrm{Mg}, \mathrm{P}$ and $\mathrm{K}$ are available, due to lower aluminum content [16], improve the soil biological properties [17]. Recent research findings strongly indicate that effect biochar is with its liming effect, water and nutrient retention capability, highly recalcitrant nature, and carbon sequestration capacity could be a potential solution for improving acid soil productivity [9].

On the other hand, the content of the elements $\mathrm{Al}$ and $\mathrm{Fe}$ can be reduced through improved drainage. However, it is difficult for farmers because the topography of the swamp is in a low basin condition so that it is challenging to be able to dispose of water during the rainy season, even it can cause water shortages in the dry season due to high soil porosity.

The productivity of rice in the swamp area is closely related to the ability of the rice plant to absorb nutrients. One of the factors that determine the ability of plants to absorb nutrients is the level of nutrient availability, among others, influenced by the level of soil acidity. The availability of nutrients in the soil to encourage an increase in absorb of nutrients by the plants. Because of the research location has a very high acidity level with a $\mathrm{pH}$ value of 3.42 - 4.12, the unavailability of nutrients in the soil can result in nutrient uptake by troubled plants, so that symptoms of nutrient deficiency, especially P. Therefore, rice culture in the freshwater swampland is necessary for rice plants that are efficient in utilizing the nutrient. Nutrient absorption is the ability of the plant relative to mine nutrients from the soil and turns it into a part of the plant. The higher the plant's ability to absorb nutrients, the higher the results obtained.

The availability of $\mathrm{P}$ nutrients in the swampland was a problem. It is necessary to apply various technological innovations. The addition of lime combined with organic fertilizer or other ameliorant is a technological innovation to increase rice yields in the swampy freshwater land. [18] compost application in swampy soils increases levels of organic Fe and $\mathrm{P}$ available in the soil. The levels of organic Fe and $\mathrm{P}$ available in the soil in water 
management are traced higher than intermittent water management. An increase in organic Fe tends to increase the available $P$.

The recommendation of farm management capacity is by arranging planting schedules to increase the cropping index. [19] reported that ciherang rice planted in shallow swamp swamps with a continuous planting system based on water and labor optimization can produce relatively good rice production, reduce labor costs, and provide opportunities to achieve IP 150.

\section{Conclusion}

Rice cultivation in the freshwater swampland was a profitable venture. Unavailability of $\mathrm{P}$ nutrients for rice plants was the main problem on acidic soil ( $\mathrm{pH} 3.32-4.12)$, caused by increased the solubility of $\mathrm{Fe}$ and $\mathrm{Al}$. Hence the adoption of farmers to various technological innovations such as liming, fertilization, and amelioration to increase soil $\mathrm{pH}$ is the key to success in rice culture in the freshwater swampland besides growing tolerant varieties - the adoption depends on farmer's education and age.

These findings recommended that management strategies in soil nutrient and education rice farmers may be more effective in attaining sustainable rice culture in freshwater swampland.

\section{References}

1. T. Yunindyawati, S. Sumarti, A. Adiwibowo, Vitayala, Hardinsyah, J. Paramita, 24, 2 (2014)

2. D. Irwandi, J. Agriekonomika, 4, 1 (2015)

3. B. E. Diagi, M. O. Nwagbara,. J. Archives of Current Research Int., 14, 2 (2018)

4. T. Wangpan, T. Taka, S. Tangjang, Pertanika J. Trop. Agric. Sc, 41,1 (2018)

5. F. Ferayanti, Int. J. of Agronomy and Agric. Research, 13, 3 (2018)

6. F. Djufry, J. Agro Saint, VI, 3 (2015)

7. Helmi. J. Pertanian Trop, 2, 2 (2015)

8. S. Nurzakiah, Nurita, L. Indrayati, J.Trop. Soil, 17, 1 (2012)

9. A. K. Berek, Pertanika J. Trop. Agric. Sc, 42, 2 (2019)

10. A. S. Kumleh, Pertanika J. Trop. Agric. Sc, 42, 3 (2019)

11. P. S. Michael, Pertanika J. Trop. Agric. Sc, 41, 4 (2018)

12. E. P. Handayani and Maswar. IOP Conf. Ser.: Earth Environ. Sci. 336012021 (2019)

13. I. Mowidu, B. H. Sunarminto, B.H. Purwanto, S.N.H. Utami, J. Agropet, 121 (2015)

14. M.F Nawaz, G. Bourie, S. Gul, F. Trolard, J.C. Mouret, M.A. Tanvir, Pakistan J. Agric. Sci. 51, 4 (2014)

15. M. Hatta, Indonesian J. of Agric. Sci. 19, 1 (2018)

16. J. Shamsuddin, I. C. Fauziah, Malaysian J. of Soil Sci, 14, (2010)

17. M. Basu, P.B.S. Bhadoria, S.C. Mahapatra, British Microbio. Research J. 1, 1 (2011)

18. I. Mowidu, J. of Sustainable Agric. 33, 1 (2018)

19. M. U. Harun, E. Saleh, C. Irsan, Proc. of National Seminar on Sub-optimal land (2014) 